\title{
Sixteenth-Century Polymaths in the Print and Publishing Business in Basel: An Intersection of Interests and Strategies (1472-1513)
}

\author{
VALENTINA SEBASTIANI \\ University of Basel \\ Translated by WENDELL RICKETTS
}

\begin{abstract}
In sixteenth-century Europe the business of printing created small intellectual communities that had the ability to manage the exigencies of the market and those of culture. In this process of continual negotiation between the interests of publishers, authors, and readers, how did men of letters lend their erudition to the service of printing? How were they able to elicit the interest of printers in publishing their works? And, above all, to what extent did their collaboration with printers impact their careers? This brief investigation analyzes the work of polymaths such as Johann Heynlin, Conrad Leontorius, Konrad Pellikan, Sebastian Brant, Jacob Wimpfeling, and Johann Reuchlin-who, acting as translators, proofreaders, and literary and typographical experts, collaborated with the Basel printer Johann Amerbach-in order to shed light on the fruitful reciprocity of printing and erudition that shaped the careers of early modern scholars and erudites.
\end{abstract}

Dans l'Europe du XVIe siècle, l'imprimerie a créé de petites communautés d'intellectuels en mesure de tenir compte aussi bien des exigences culturelles que de celles du marché. À travers la continuelle négociation entre les intérêts des éditeurs, des auteurs et des lecteurs, comment ces hommes de lettre ont-ils mis leur érudition au service de l'imprimerie? Comment arrivaient-ils à intéresser les éditeurs à leur travail ? Et surtout, dans quelle mesure leur collaboration avec ces éditeurs a-t-elle influencé leur carrière? Cette brève enquête analyse le travail de savants polymathes tels que Johann Heynlin, Conrad Leontorius, Konrad Pellikan, Sebastian Brant, Jacob Wimpfeling et Johann Reuchlin, qui ont travaillé en tant que traducteurs, correcteurs d'épreuves, et d'experts typographes et littéraires avec l'imprimeur bâlois Johann Amerbach. Elle met ainsi en lumière la collaboration fructueuse de l'imprimerie et de l'érudition et son impact sur la carrière des intellectuels et des érudits de cette époque.

\footnotetext{
Qver the course of the last two decades, the methodological and epistemological space that once separated disciplines engaged in the study of print in the early modern age has progressively narrowed. The phenomenon of print is now understood in its widest sense: as a technical innovation, a new kind of merchandise, and a privileged forum for written communications. Alongside questions of the production and distribution of printed texts, the development of multiple lines of investigation is slowly but
} 
surely closing the distances among bibliography, the history of the book, and the study of the cultural, social, and religious practices tied to book printing. These new investigative approaches simultaneously integrate what the late New Zealand bibliographer and teacher Donald F. McKenzie called the "sociology of the text."' Specifically, the more incisive adoption of market perspectives within investigations of the activities of printers and printing houses, on the one hand, and, on the other, a more frequent recourse to paratextual analysis, allow bibliographers, literary scholars, and historians of the book, of economics, and of cultural studies to combine their unique discourses in the study of the ars artificialiter scribendi. ${ }^{2}$ The result is that the technical dynamics of typography and printing today appear much less separate from the strategies of communication represented by printed books themselves.

The many recent analyses of the print industry in Europe are not solely evidence of epistemological productivity inspired by new questions. ${ }^{3}$ Rather, they allow scholars to see-perhaps for the first time-a concrete opportunity to encompass, within an integrated view, the terms of McKenzie's 1986 advice to bibliographers:

1. Donald F. McKenzie, Bibliography and the Sociology of Texts, 3rd ed. (Cambridge: Cambridge University Press, 1999), 5. For a view of the sociology of texts that diverges slightly from McKenzie's, see Jerome J. McGann, The Textual Condition (Princeton: Princeton University Press, 1991), especially 69-87.

2. The scholarly interest in paratextual analysis within research on the history of the book has grown remarkably since Gérard Genette's seminal work Seuils. Examples include: Karl A. E. Enenkel, et al., eds., Cognition and the Book: Typologies of Formal Organisation of Knowledge in the Printed Book of the Early Modern Period (Leiden: Brill, 2005); Frieder von Ammon, et al., eds., Die Pluralisierung des Paratextes in der Frühen Neuzeit: Theorie, Formen, Funktionen (Berlin: Lit, 2008); Roger Chartier, Inscrire et effacer. Culture écrite et littérature (XIe-XVIIIe siècle) (Paris: Gallimard, 2005); Anthony Grafton, The Culture of Correction in Renaissance Europe (London: British Library, 2011). For an updated selected bibliography see Helen Smith and Louise Wilson, eds., Renaissance Paratexts (Cambridge: Cambridge University Press, 2011), 264-67.

3. Examples of recent research on the European printing industry in the early modern age include Angela Nuovo, The Book Trade in the Italian Renaissance (Leiden: Brill, 2013); Ian Mclean, Learning and the Market Place: Essays in the History of the Early Modern Book (Leiden: Brill, 2009); Andrew Pettegree, The French Book and the European Book World (Leiden: Brill, 2007); Stefan Oehmig, ed., Buchdruck und Buchkultur im Wittemberg der Reformationszeit (Leipzig: Evangelische Verlagsanstalt, 2016); Enno Bünz, ed., Bücher, Drucker, Bibliotheken in Mitteldeutschland. Neue Forschungen zur Kommunikationsund Mediengeschichte um 1500 (Leipzig: Leipziger Universitätsverlag, 2006). 
For a book is never simply a remarkable object. Like every other technology, it is invariably the product of human agency in complex and highly volatile contexts which a responsible scholarship must seek to recover if we are to understand better the creation and communication of meaning as the defining characteristic of human societies. ${ }^{4}$

In other words, the history of the book can provide a fundamental contribution to the reconstruction of the manifold phases implicated in the production and dissemination of written communications and, at the same time, facilitate a closer intellectual dialogue among scholars interested in the study of the literary, religious, cultural, technical, and economic history of early modern Europe, including librarians and bibliographers who work in cultural-heritage institutions. By concentrating investigations within the printing house, such an approach allows a study of printed texts that focuses on their material, technical, and economic semantics. It identifies the mechanical processes by which manuscript pages were transformed into the printed word; analyzes the quality and quantity of that production; evaluates both cost and production times and the publishing industry's profits and losses; and includes a close examination of the varied social and professional worlds implicated in the processes of book-making. On the other hand, by looking beyond printing houses, historians of the book have shown themselves capable of analyzing printed works from multiple perspectives, including in terms of their value as "mass media" and as instruments of communication whose strategies of distribution and circulation can be reconstructed: where they were sold, for what price, and by whom the semantic content (transmitted by the printed page) was read, discussed, or criticized.

In order to shed light on what took place simultaneously both within and outside of the print shop, it is nonetheless essential that the printing house door remain open at all times to the researcher's analytic gaze. In such a way, we may observe not only that reams of paper, type cases, books and manuscripts, trained workers, business agents, and editorial consultants entered and exited, but we can also recognize that presiding over the printing of a manuscript, operating a printing press, forging a new series of punches, selling bales of books at the fairs, or choosing new manuscripts for publication through an 
evaluation of market demands and the desires of the reading public were all activities aimed at the same objective: the production and distribution of the written word.

That printed books were the result of a negotiation of material, economic, social, and cultural practices becomes especially evident if we analyze partnerships among erudite scholars and learned printers in the early modern age. Historical studies on this subject have stressed the predominant role of print in bringing visibility, fame, and success to the authors of printed texts. ${ }^{5}$ Recent scholarly attention, moreover, has focused on the concrete support that expert scholars and polymaths provided to printers and publishers. Anthony Grafton, in particular, has shown us the multiple roles played by scholarly correctores for the printing industry. ${ }^{6}$

But in what ways were the knowledge and expertise of erudites and polymaths made available to printers? How did scholars at that time arouse publishers' interest in their works? And what were the terms and conditions that governed their collaborations with the printer-publishers of their day?

In an attempt to outline possible responses to such queries, this article will bring to light details of the partnerships between learned scholars and Johann Amerbach's famous printing house in Basel. In so doing, it aims to improve our understanding of the economic and cultural significance of those occasions when the multifaceted erudition of such scholars and polymaths was placed at the service of the production and dissemination of the printed word.

Because of its reputation as a centre of scholarly publishing, the city of Basel offers an especially fruitful ground for an investigation of the many-sided contributions of polymath and erudite scholars to the publishing industry. In an area of the Rhine known as a cradle of humanistic thought and study, figures such as theologians Johann Heynlin and Konrad Pellikan, legal scholars such as Sebastian Brant, noted experts on Hebrew and Greek such as Johann Reuchlin, Conrad Leontorius and Bruno Amerbach, and men of letters and humanists such as Jacob Wimpfeling were active participants in the production and distribution

5. Erasmus of Rotterdam is the specimen case. See, for example, Lisa Jardine, Erasmus, Man of Letters: The Construction of Charisma in Print (Princeton: Princeton University Press, 1993) and Hilmar M. Pabel, Herculean Labours: Erasmus and the Editing of St. Jerome's Letters in the Renaissance (Leiden: Brill, 2008).

6. Anthony Grafton, The Culture of Correction in Renaissance Europe (London: British Library, 2011). 
of the books that Amerbach produced in his printing house. But such men were much more than that: in Amerbach's printing house, which served as a sort of laboratory for the formulation and deployment of new scholarly and technical printing processes, they developed skills that dynamically modified the meaning and goals of their own work as professional humanists. ${ }^{7}$

\section{Scholarly printing for the market}

If it is true that, in the first decades following its invention, Gutenberg's printing press was a commodity without an actual market, it is also true that before the end of the sixteenth century the printed book had become the favoured mechanism for the manufacture of written communications. For a second generation of printers, the financial failure of many of the earliest printing houses left no doubt about the necessity of creating partnerships with large international merchants for the development of their businesses over the long term. The result was a drastic restructuring within the entire publishing industry and, as a consequence, an appreciable reduction in the number of active printing houses. Those that remained were largely concentrated in centres of international commerce, but they also had more secure access to the financial resources and established networks of local merchants. ${ }^{8}$ Nevertheless, this vigorous nudge in the direction of the transformation of the printed book into an international luxury item did not save printers from the occasionally dramatic fluctuations of a book market whose stability was decidedly uncertain. Their task was not solely to ensure financial backing for the necessary initial investment in equipment, paper, and labour, but also to evaluate accurately the time and costs that were involved in the production of a printed book and, above all, to predict

7. This brief essay is part of a broader ongoing research that is financed by the Swiss National Science Foundation (SNSF) at the University of Basel.

8. With regard to the bankruptcy of many proto-printing houses and the general restructuring of the book-printing industry, see Andrew Pettegree, The Book in the Renaissance (New Haven: Yale University Press, 2010), 53-55, 62. The reduction in active printing houses and their concentration in commercial centres is discussed, with respect to Germany and Switzerland, in Thomas Fuchs, "Einleitung. Buch und Reformation," in Buch und Reformation: Beiträge zur Buch-und Bibliotheksgeschichte Mitteldeutschlands im 16. Jahrhundert., ed. Enno Bünz et al. (Leipzig: Evangelische Verlagsanstalt 2014), 9-38; and Urs Leu, "Die Bedeutung Basel als Druckort im 16. Jahrhundert," in Basel als Zentrum des geistigen Austauschs in der frühen Reformationszeit, ed. Christine Christ-von Wedel, Sven Grosse, and Berndt Hamm (Tübingen: Mohr Siebeck, 2014), 53-78, especially 54-58. 
whether the volumes they produced would sell. Among the options printers had available to them to weather the uncertainties of the production and distribution of books, most chose to publish established "bestsellers." Editions and reprints of traditional works of jurisprudence and theology, sermons, and textbooks of medieval scholarship, though hardly original, nonetheless found a ready market. A smaller number of printing houses, instead, counted on turning new editions by contemporary humanists of classical and theological works in Greek and Latin into commercial successes.

"The invention of printing was not the work of scholars," remarks Andrew Pettegree, ${ }^{9}$ nor was its full affirmation possible without the financial support of established international merchants. At the point at which the mission of some printers became to "edit properly, provide competent commentary, publish and translate the body of classical texts capable of transmitting the experience and knowledge of the ancient Mediterranean to modern Europe," ${ }^{10}$ the multiform contribution scholars could offer to the printing industry became all the more indispensable as a function of the sophistication of a printing house's editorial project.

Between the end of the fifteenth century and the beginning of the sixteenth, the most celebrated example of a partnership among printers, merchants, and scholars was the one established in 1494 in Aldo Manuzio's printing house in Venice, nearly fifteen years after such collaborations had been undertaken in Basel. ${ }^{11}$

\section{Pettegree, The Book in the Renaissance, 21.}

10. "éditer correctement, commenter avec compétence, publier et traduire cet ensemble de textes classiques qui transmettaient à l'Europe moderne l'expérience et le savoir de la Méditerranée antique": Marc Fumaroli, "Préface," in Les premiers siècles de la République européenne des Lettres, ed. Marc Fumaroli (Paris: Alain Baudry, 2001), ix-xviii, xi.

11. Martin Lowry's The World of Aldus Manutius: Business and Scholarship in Renaissance Venice (Oxford: Blackwell, 1979) remains an essential text for understanding the history of Aldo Manuzio's printing house. 


\section{The publishing industry in Basel}

Though the art of printing was invented in Mainz, Basel nonetheless dragged it from the mire. ${ }^{12}$

The prideful statement (above) appeared in 1472 as part of some introductory verses in one of the first publications to issue from the presses of Michael Wenssler in Basel. It eloquently testifies to an awareness that printers in Basel developed quite quickly: if they wished to guarantee the expansion of their businesses, they needed strategic alliances with both international business concerns and learned scholars. Already in the Middle Ages, Basel was a flourishing centre for the warehousing of goods on the move between northern and southern Europe. Among other considerations, its geographical location offered printers and merchants special access to international transportation up and down the Rhine. The notably entrepreneurial approach of printers, which allowed them to attract the capital necessary to finance their publications; the relative certainty that their books would find wide and ample distribution; and other infrastructural and political conditions in Basel that especially favoured the development of a printing industry-all ensured that books published in Basel would find their way to the major European marketplaces. ${ }^{13}$

The metaphor of the "mire" from which, according to Wenssler, print had been dragged by the publishing industry in Basel may nonetheless refer not solely to the successful elimination of the conditions that had impeded printing from developing in a more blatantly commercial direction. In addition to driving commerce and production in the book trade, Basel's printer-publishers also served as an extraordinary laboratory in which the great potential inherent in partnerships among printers, scholars, and merchants could be tested and developed.

If the goal of such activity was to supply the marketplace with new kinds of books intended to strengthen the growing humanist movement north of the Alps, in a subtler sense the publishing industry in Basel was, from its origins,

12. "Artem pressurae quanquam mogu[n]cia finxit. E limo traxit hanc Basileam tamen": Gasparinus Barzizius, Epistolae (Basel: Michael Wenssler and Friedrich Biel, ca. 1472) (GW 3676), fol. [1]. Copy consulted: UBBS, call number: Inc 581:3.

13. Regarding the favourable conditions offered by Basel for the development of publishing, see Martin Steinmann, “Der Basler Buchdruck im 16. Jahrhundert: Ein Versuch," Librarium 53 (2010): 79-98. 
also prepared to extract the texts of the classical tradition from the symbolic mire in which they had lain for centuries and to provide them with new and fruitful grounds on which to be disseminated. Indeed, it was no accident that Wenssler's verses were placed as an introduction to the first Basel edition of the Epistolae of Gasparino da Barzizza (1360-1431), considered, within the transalpine humanist movement, to represent a new milestone in the study of the rhetorical and grammatical elegance of Cicero. ${ }^{14}$

Along the same lines as Wenssler, but with greater business acumen and a sounder intellectual foundation, the printer Johann Amerbach (ca. 1443-1513) succeeded in making partnerships with scholars and merchants a permanent feature of his printing and publishing business. In its thirty-five years of activity between 1478 and 1513, Amerbach's press published some hundred editions that left a profound mark on Basel's reputation as a centre of scholarly publishing. Amerbach was able to attract the financial backing of no less a leading book merchant than Anton Koberger (ca. 1440-1513) ${ }^{15}$ of Nuremberg. Moreover, he secured the ongoing participation of other scholar-polymaths in carrying out his ambitious editorial mission. The many paratextual elements that appeared in the opening pages or as marginal commentaries in Amerbach's books, along with his rich correspondence, teach us a great deal about the intellectual power Amerbach's printing house required and the means by which he went about recruiting it.

\section{At work in Johann Amerbach's printing house}

As a student in the Faculty of Arts at the University of Paris and a pupil of the theologian Johann Heynlin (ca. 1430-96) at the Sorbonne in the 1460s, Johann

14. The editio princeps of Gasparino da Barzizza's Epistles, edited by Johann Heynlin, was printed in 1470 by the presses of Ulrich Gering, Martin Crantz, and Michael Friburger at the Sorbonne (GW 03675). Regarding Barzizza, his work as a teacher of Latin grammar, and his influence on the education of humanists, see Guido Mertelotti, "Barzizza, Gasparino," in Dizionario Biografico degli Italiani (Rome: Istituto della Enciclopedia Italiana 7, 1965), 34-39; and R. G. G. Mercer, The Teaching of Gasparino Barzizza: With Special Reference to His Place in Paduan Humanism (London: Modern Humanities Research Association, 1979). See, also Carl Joachim Classen, Antike Rhetorik im Zeitalter des Humanismus (München: K. G. Saur, 2003), especially 10-11 and 157-58.

15. Oskar von Hase's Brieffbuch der Koberger zu Nurmbergk (Leipzig: Breitkopf und Härtel, 1881) provides detailed information on the Amerbach/Koberger partnership. 
Amerbach acquired an excellent command of Latin and a solid background in the realist tradition of scholasticism. Both these specializations were decisive in guiding the editorial mission that, beginning in 1478, Amerbach began to implement at his printing house in Basel. At a remarkable pace, given the technical capacities of his time, Amerbach published treatises, collections of letters, and grammars for the study of Latin in the most recent humanist tradition and, beginning in 1489, editions of texts written by the Fathers of the Church. ${ }^{16}$

Amerbach's catalogue did not reflect solely the interests of the educated and scholarly public in new printed texts or their tastes. Rather, it was a litmus test that provided valuable information regarding the success of the material and scholarly practices he deployed in realizing his books.

The education Amerbach provided to his sons Bruno (1484-1519) and Basilius (1488-1535) during the years they studied at the University of Paris between 1501 and $1508{ }^{17}$ provides a useful point of reference for considering the scholarly competencies Amerbach required in the daily running of his printing house. In order to ensure that his sons would be capable of carrying on the work of editorial correction and collation of texts intended for his presses, Amerbach counselled them to apply themselves rigorously ("to study hard"), ${ }^{18}$ particularly in Latin, Greek, and Hebrew. He not only expected their

16. In the absence of a comprehensive study of Johannes Amerbach, see Manfred Welti, "Amerbach, Johann," in Contemporaries of Erasmus: A Biographical Register of the Renaissance and Reformation, 3 vols., ed. Peter G. Bietenholz and Thomas B. Deutscher (Toronto: University of Toronto Press, 1985-87), 1:47; and Alfred Hartmann, et al., eds., Die Amerbachkorrespondenz. Die Briefe aus der Zeit Johann Amerbachs, 1481-1513 (Basel: Universitätsbibliothek, 1942-2010) (hereinafter AK). The first volume of Amerbach correspondence has been broadly summarized, and the letters translated and commented on, by Barbara C. Halporn in The Correspondence of Johann Amerbach: Early Printing in Its Social Context (Ann Arbor: University of Michigan Press, 2000). Halporn's translation is used here for citations from the Amerbach's letters. On Amerbach's editorial production, see Pierre Louis van der Haegen, Basler Wiegendrucke: Verzeichnis der in Basel gedruckten Inkunabeln mit ausführlicher Beschreibung der in der Universitätsbibliothek Basel vorhandenen Exemplare (Basel: Universitätsbibliothek Basel, 1998). See also the list of editions published by Amerbach in the Index typographorum editorumque Basiliensium (ITB), online, accessed 11 May 2016, http://www.ub.unibas.ch/itb/druckerverleger/johannes-amerbach.

17. On the scholarly education received by Bruno and Basilius Amerbach see Valentina Sebastiani, "Childhood and Emotion in a Printing House (1497-1508)," in Childhood and Emotion Across Cultures 1450-1800, ed. C. Jarzebowski and T. M. Safley (London: Routledge, 2013), 143-56. For their biobibliographical profile, see Bietenholz and Deutscher, eds., 1:46 and 1:42 respectively.

18. AK, vol. 1, ep. 128. 
language skills to be grammatically exemplary-"I do care about grammatical agreement!" Amerbach wrote, correcting the error-filled letters he received from his sons ${ }^{19}$ - but he also intended such skills to be finalized in the production of original texts ("I want and expect you to write out of your own head") ${ }^{20}$ for possible use as commentaries or introductions to future printed works. This was the case, for example, with the many introductions that Bruno and Basilius wrote to the volumes of St. Jerome's Opera omnia in $1516 .{ }^{21}$ The education of Amerbach's sons prior to their taking up the work of the printing house was expected to enable them to participate actively in the research, copying, and translation of texts intended for the Amerbach presses as well as to qualify them to propose new texts for publication.

In 1504, for example, Bruno was entrusted with the task of reporting to his father on the progress of the hand-copying in Paris of a number of treatises that Amerbach required for the preparation of his edition of the complete works of St. Augustine.22 In 1507, furthermore, Bruno suggested the printing of well-known texts that had been expertly retranslated by such contemporary scholars as Jacques Lefèvre d'Étaples. ${ }^{23}$

The mechanical reproduction of the written word in such a way that it could be "read without getting tired and without the need for eyeglasses"24 nonetheless required the acquisition of other, more technical skills. It is known that, beginning in 1486, Amerbach began using the littera antiqua or Roman type for the printing of his humanistic texts; ${ }^{25}$ he was the first to do so

19. AK, vol. 1, ep. 191.

20. AK, vol. 1, ep. 225.

21. Jerome, Opera omnia (Basel: Johannes Froben, 1516) (VD16 H 3482). Copy consulted: UBBS, call number: FL II 3-7. Bruno's and Basilius's prefatory letters to the reader are appended to volume 5; in addition, Bruno wrote introductions to volumes $6,7,8$, and 9 .

22. AK, vol. 1, ep. 238.

23. AK, vol. 1, ep. 369.

24. It was thus that Enea Silvio Piccolomini described the Gutenberg Bible in his famous letter to Juan de Carvajal of 12 March 1455: "Non vidi biblias integras, sed quinterniones aliquot diversorum librorum, mundissime ac correctissime litterae, nulla in parte mendaces, quos tua dignatio sine labore et absque berillo legeret." On Piccolomini's letter, see Martin Davies, "Juan de Carvajal and Early Printing: The 42-Line Bible and the Sweynheym and Pannartz Aquinas," The Library 18 (1996): 193-215.

25. On the typefaces used by Amerbach, see Martin Steinmann, "Die humanistische Schrift und die Anfänge des Humanismus in Basel," Archiv für Diplomatik, Schriftgeschichte, Siegel- und Wappenkunde 
among printers north of the Alps. In order to encourage Bruno and Basilius to familiarize themselves with the humanities' new chirographic and typographic styles, the Cistercian monk, Conrad Leontorius (ca. 1465-1511), a humanist scholar and Greek expert, but above all an active consultant to the Amerbach printing house beginning in the last decade of the fifteenth century, urged Amerbach to "Write your sons not to continue to disfigure their handwriting with barely civilized gothic script, but to apply a modest measure of attention to forming their Latin letters in Roman style, so that they will develop their hands as well as their minds."26

Leontorius's advice to the two young men, both pedagogical and calligraphic in nature, reveals the essential role that Amerbach's exactitude in the preparation and printing of his books played in creating the "many famous works" that caused Amerbach's name to be "heard on the lips of all learned men." ${ }^{27}$ The adoption of the Roman type conferred greater sharpness to the printed page, which was also occasionally embellished with woodcuts and elegiac distichs. At the same time, the attention lavished on paratextual elements (summaries, tables, printed marginal commentaries, and bibliographical references); the choice to print books in a variety of formats; the numbering and indexing of the pages-all these elements, in fact, reflect such an advanced approach to printing and publishing that they rendered the books produced by Amerbach additionally valuable in his readers' estimation. ${ }^{28}$

Indeed, it was the opinion of the theologian, preacher, and bibliophile, Johann Heynlin, the head editor at Amerbach's printing house from 1484 to 1496, that if the texts of the manuscript era, "which [were] written without break and without any divisions placed between" were to be henceforward "divided into chapters and prefaced with summaries [...] [their] ideas and

\footnotetext{
22 (1976): 376-437.
}

26. AK, vol. 1, ep. 265. The first letter from Conrad Leontorius to Amerbach is dated 28 April 1491 (AK, vol. 1, ep. 18). For a bio-bibliographical profile of Leontorius and his partnership with Amerbach's printing-house, see Müller, Habit und Habitus, 296-313; and Wolff, "Conradus Leontorius Biobibliographie."

27. AK, vol. 1, ep. 19. Similarly, in a previous letter, Leontorius had written that Amerbach's "many works $[\ldots]$ sealed his reputation with lasting glory": AK, vol. 1, ep. 18.

28. Regarding the techniques of mise en page and their evolution in the publishing industry of the early modern age, see Henri-Jean Martin, Mise en page et mise en texte du livre français: La naissance du livre moderne (XIVe-XVIIe siècle) (Paris: Ed. du Cercle de la Librairie-Promodis, 2000). 
purpose may be explained and thus they may become less difficult and more intelligible to the reader." As a result, Heynlin would provide "something very valuable to all potential readers" in Amerbach's edition of St. Ambrose's Opera omnia. Specifically, he would "see to it that each treatise of our holy doctor is divided into chapters and that summaries, containing in brief compass the substance of each, appear in a head-note to prepare the mind of the reader for easier understanding." ${ }^{29}$

The diligence and precision required of the editorial staff in the use of these technical and graphic tools, understood as they were as support for the comprehension and assimilation of the contents of the books, were such that they necessitated the skills of established scholars or, occasionally, of young, particularly gifted students. The Franciscan friar, philologist and fine expert of Hebrew, Konrad Pellikan, in fact, while still a young student, was hired by Amerbach to divide the works of St. Augustine into chapters and write a brief summary and introduction for each chapter ${ }^{30}$ on the model of Heynlin's work, in preparing the works of St. Ambrose for publication. Pellikan was later recruited to index St. Jerome's collected works. ${ }^{31}$

Along with Pellikan, Heynlin, and Leontorius, the celebrated jurist and humanist Sebastian Brant (1457-1521) also personally saw to the arrangement, the structure, and layout of some Amerbach editions. ${ }^{32}$ In his introduction to an

29. AK, vol. 1, ep. 23. The letter was printed as the preface to the 1492 edition of Ambrose's Opera, 3 vols. (Basel: Johann Amerbach, 1492) (GW 1599), vol. 1, fols. $6^{\mathrm{r}}-7^{\mathrm{r}}$. Copy consulted: UBBS, call number: FJ II 1-3. On the subject of Heynlin's many and varied contributions to the editions published by Amerbach, see Valentina Sebastiani, "Die kulturelle, geistige und materielle Bedeutung des Bündnisses zwischen Humanismus und Druckwesen im Basel der frühen Neuzeit," in Basel als Zentrum des geistigen Austauschs in der frühen Reformationsheit, ed. Ch. Christ-von Wedel, S. Grosse, and B. Hamm (Tübigen: Mohr Siebeck, 2014), 79-95; and Piroska Máthé, "Heynlin de Lapide, Johannes," in Neue Deutsche Biographie 9 (München: Bayerische Staatsbibliothek, 1972), 98-100.

30. Konrad Pellikan himself told about his engagement with Amerbach and then with Froben's printing press in his Chronikon, for which see Bernhard Riggenbach, ed., Das Chronikon des Konrad Pellikan (Basel: Bahnmaier Verlag, 1877); see also, Grafton, 14-16 and Bietenholz and Deutscher, eds., 3:65-67.

31. In a manuscript note in his personal copy of St. Jerome's Opera omnia, now held in the Zürich Zentralbibliothek (call number: III ZZ 120-123: vol. 8, sign. A1v), Konrad Pellikan wrote: "Conradij Pellikani|| opera hic|| Appendix parabis|| 1516||). The edition of St. Jerome's Opera omnia was initially undertaken by Amerbach and printed, with the fundamental help of Erasmus of Rotterdam, by Johann Froben in May 1516.

32. On Brant's bio-bibliographic profile, see Bietenholz and Deutscher, eds., 1:160-61. 
edition of the Bible printed for Amerbach by Johann Froben and Johann Petri, Brant commented upon the complex system of symbols, letters, and numbers printed in the margins of the text that were meant to guide the reader toward a more efficient use of the work. ${ }^{33}$ A similar explanation written by Brant in the prefatory letter as well as in some verses also appeared on Pope Gregory IX's Decretales, published by Amerbach and Froben in 1500. Brant's editorial work was required, in fact, also for the publication of juridical and theological editions printed by Amerbach or by his associates, Johann Froben and Johann Petri. ${ }^{34}$

\section{Securing the help of scholars in the printing and publishing business}

As to why established scholars agreed to shoulder the "[not] small task" ${ }^{35}$-indeed, the occasionally tedious and repetitive one of finding, editing, correcting, translating, preparing, and formatting texts-various answers are possible.

First and foremost, Amerbach's editorial approach responded to scholars' needs and interests. Sebastian Brant, professor of law at the university of Basel in 1500, for example, in his prefatory letter to Gregory IX's Decretales exhorted his students to buy the book because it would help to have amended and corrected texts such as those printed by Amerbach close at hand ("ad manu”) during his lessons. ${ }^{36}$ Amerbach's publications testify, in fact, to the effort the Basel printer made to follow the example of the Italian humanists and to extend contemporary interest in restoring the precision and clarity of the written word (and thus a proper understanding of its meaning) into the areas of theology, jurisprudence, and manuals on preaching. Alongside the rigour and thoroughness that Amerbach brought to the reintroduction of the texts he chose to publish, ${ }^{37}$ he shrewdly employed printing techniques that

33. The preface to Biblie iampridem renovate, fol. $1^{\mathrm{v}}$, is an example. Brant's involvement in the production of other editions produced by Amerbach is discussed in Thomas Wilhelmi, ed., Sebastian Brant. Forschungsbeiträge zu seinem Leben, zum «Narrenschiff» und zum übrigen Werk (Basel: Schwabe, 2002). 34. Gregory IX, Decretales, ed. Sebastian Brant (Basel: Johann Amerbach, Johann Froben, 1500) (GW 11502). Copy consulted: UBBS, call number: Nn VIII 3. Brant's explanations are on sign. Aa $1^{\mathrm{v}}$ and $\mathrm{Aa}^{\mathrm{v}}$. 35. AK, vol. 1, ep. 23.

36. Sebastian Brant: "Brevis accommoda huius operis nuper in Basilea impressi commendation," in Gregory IX, sign. Aa1.

37. On Amerbach's proverbial accuracy and his passion for textual and linguistic correctness see Grafton, 29. 
were as innovative as they were designed to reconcile humanist thought with the printer's art, ideals of linguistic purity and intellectual modernization with the material aspects of his printed books, content with its container. In his introduction to the works of St. Ambrose, in fact, Heynlin directed praise to Amerbach along these lines:

You have equipped the church of God with excellent arms through repeated printings of the canonical books of the Old and New Testament. [...] I need not advise you to watch carefully to see that they [the works of the Fathers of the Church] are properly corrected, emended, and accurately executed. For you have customarily exercised such caution in all those books that you have printed previously by your toil and expense as they themselves give indisputable testimony. [...] I have read no books made by this art that I considered more correct or produced with greater precision and care than yours. ${ }^{38}$

The praise and commendations heaped upon Amerbach in letters from colleagues and scholars in the Republic of Letters north of the Alps, in fact, reveal not only their genuine enthusiasm for his editorial projects but also their authentic interest in becoming involved in them. The first of the letters that Leontorius sent to Amerbach is an example. In April 1491, Leontorius wrote:

Considering how much I esteem the prestige and glory of your name in your handsomely produced books, I would do you an injustice if I did not serve the glory of your name by services however small. I shall do this straightaway if I can be of assistance to you in the book business either by advice or resources. ${ }^{39}$

Declarations of principle aside, however, the establishment of partnerships with publishers represented an advantage not solely for the cause of bonae litterae but personally for scholars themselves.

Though the amounts were risible, the compensation scholars received for their work from printers nonetheless represented a supplement to their normally 
low incomes. ${ }^{40}$ Those who contributed in various ways to the preparation of texts for printing might additionally receive a complimentary copy or, at least, a discount on the purchase price. ${ }^{41}$ But a wide range of other solutions were also negotiated regarding the compensation provided to editorial consultants and scholarly workers.

Johann Reuchlin (1455-1522), for example, a legal scholar and a refined expert in Latin, Greek, and Hebrew, worked closely with Amerbach's printing house. Between 1470 and 1482 Reuchlin studied at the universities of Freiburg, Basel, Paris, and Tübingen. He had earned significant recognition among scholars, especially for his pioneering work in the study of Hebrew and the Cabala. ${ }^{42}$ The terms of Reuchlin's association as a proofreader for Amerbach provide additional details regarding Amerbach's strategy of involving talented scholars as consultants and workers in his firm; it was one means of establishing his business more solidly. Around 1510, in fact, Amerbach offered to buy and sell almost 1,500 unsold copies of Reuchlin's Grammar of the Hebrew Language that had been printed in Tübingen, solely in order to convince the great polymath to correct some of the quotations in Hebrew in St. Jerome's Opera omnia that Amerbach intended to publish. ${ }^{43}$

Although scholars in Amerbach's printing house were not always paid a salary, their presence there gave them both visibility and professional prospects that would have been unthinkable in the era of the manuscript book. Through the dedications and the introductions they wrote for published texts, for example, they could strengthen intellectual and professional ties and create

40. Though precise data on the salaries of scholarly workers in Amerbach's printing house are missing, it is of interest here that, in 1497, Jacob Wimpfeling gave the copyist of some treatises by St. Augustine, which Amerbach needed for his forthcoming edition, one Rhenish florin: "I plan to pay the copyist who will get about one Rhenish florin" (AK, vol. 1, ep. 68). The eleven volumes of the edition of the works of St. Augustine printed between 1505 and 1506 had a market value of six Rhenish florins: see Riggenbach, 95.

41. That was true in the case of Pellikan, who received a copy of the edition of the works of St. Augustine (regarding which, see Riggenbach, 95). The same did not occur for Conrad Leontorius, however. Despite the work he had done, Leontorius complained to Amerbach in June 1506 that he had yet to receive a single copy (AK, vol. 1, ep. 313). Wimpfeling, on the other hand, more modestly requested a discount on the purchase price (AK, vol. 1, ep. 302).

42. On Reuchlin's studies and scholarly expertises, see Bietenholz and Deutscher, eds., 3:145-50.

43. AK, vol. 1, ep. 434. Reuchlin's work is De rudimentis hebraicis, published by Thomas Anshelm in Tübingen in 1506 (VD16 R 1252). 
new ones. ${ }^{44}$ In addition, as mediators between manuscript owners (largely monastery libraries) and printers, they could develop advantageous contacts within the Republic of Letters across Europe. ${ }^{45}$ Their special connection to Amerbach, finally, allowed them to propose "wish lists" of texts that deserved to be published, among which there often appeared works they themselves had written or edited. Jacob Wimpfeling's insistence that Amerbach print some of Wimpfeling's own works, which he touted as "the most useful for the glory of God, for the honour of our homeland and the glory of Germany,"46 is but one example.

\section{Conclusion}

The few examples considered here of the involvement of scholar-polymaths in Johann Amerbach's printing house were intended to show both the type of scholarly work that was so necessary to the functioning of the renowned printing house in Basel and the variety of opportunities that the printing and publishing business offered to its scholarly consultants and associates. In fact, the sodalitas of learned men of letters that congregated around Johann Amerbach saw publishing as an extraordinary ally in the cultural and spiritual renewal that was their goal as humanists. They became, as well, refined connoisseurs of the book industry, well acquainted with both its social and economic value and its advantages. The bustle of learned men in and around Amerbach's printing house-as they sought publishable manuscripts, corrected and translated texts for publication, fine-tuned new, more efficient techniques of pagination, or wrote dedications and introductions-represented a new opportunity for them to employ their scholarly expertise in new and fruitful ways, to broaden and reinforce their intellectual and professional networks, and to develop strategies

44. Such was the case with the dedications that appeared in the front matter of Johann Reuchlin's De verbo mirifico, sign. $\mathrm{a}^{\mathrm{v}}$, $\mathrm{a} 2^{\mathrm{r}}$, for an interpretation of which, see Halporn, 64-65. For an updated bibliography on the use and significance of prefatory and dedicatory letters printed in books see Andre Horch, Buchwidmungen der Frühen Neuzeit als Quellen der Stadt-, Sozial- und Druckgeschichte (Frankfurt am Main: Peter Lang, 2014), especially 248-61.

45. Jacob Wimpfeling showed, in particular, remarkable entrepreneurial ability in the search for manuscripts. Relying on his broad intellectual network, he frequently arranged successful negotiations for Amerbach's needs. See, for example, AK, vol. 1, eps. 68, 302, 325.

46. AK, vol. 1, ep. 28. 
for self-promotion within the Republic of Letters. As Johann Heynlin's own words indicate, new editorial and publishing procedures helped reinforce the awareness among scholars that they could instrumentally affect the dissemination of their own ideas and values. Simultaneously, new editorial conventions and processes, along with the entrepreneurial possibilities they introduced, dynamically modified the humanist ideal of the contemplative life that scholars had pursued since generations before the advent of print. ${ }^{47}$ 